\title{
Striking life events associated with primary breast cancer susceptibility in women: a meta-analysis study
}

\author{
Yan Lin ${ }^{1 \dagger}$, Changjun Wang ${ }^{1 \dagger}$, Ying Zhong ${ }^{1}$, Xin Huang ${ }^{1}$, Li Peng $^{1}$, Guangliang Shan ${ }^{2}$, Ke Wang $^{2}$ and Qiang Sun ${ }^{\text {1* }}$
}

\begin{abstract}
Purpose: The association between striking life events, an important stress and acute anxiety disorder, and the occurrence of primary breast cancer is unclear. The current meta-analysis was designed to assess the relationship between striking life events and primary breast cancer incidence in women.

Methods: Systematic computerized searching of the PubMed, ScienceDirect, Embase, and BMJ databases with the combinations of controlled descriptors from Mesh, including breast cancer, breast tumor, cancer of breast, mammary carcinoma, life events, life change events, case-control studies, case-base studies, cohort study, and cohort analysis and identified a total of 307 papers published from January 1995 to April 2012. Following evaluation of methodological quality with the Downs \& Black criteria, seven case-control or cohort studies were selected and the association between striking life events and primary breast cancer incidence in women was measured using random effect or fixed-effect odds ratios combined with 95\% confidence interval.

Results: The seven studies included in the final meta-analysis included 99,807 women. A meta-analysis showed that the pooled OR for striking life events and breast cancer was 1.51 (95\% Cl 1.15-1.97, $P=0.003)$, indicating that women with striking life events were at 1.5-fold greater risk of developing breast cancer. The pooled OR for severe striking life events and breast cancer was 2.07 (95\% Cl 1.06 - 4.03), indicating that women with severe striking life events were at 2-fold greater risk of developing breast cancer.
\end{abstract}

Conclusions: The current meta-analysis showed significant evidence for a positive association between striking life events and primary breast cancer incidence in women.

Keywords: Breast cancer, Striking life events, Severe life events, Risk

\section{Introduction}

Primary breast cancer is one of the main public health problems worldwide. Over 1.3 million women are diagnosed annually with primary breast cancer and approximately 458,000 will die from the disease [1]. Various risk factors for primary breast cancer have been identified $[2,3]$, with environmental and life style factors being important $[3,4]$. In contrast, the association between stress and breast cancer occurrence is unclear, with several

\footnotetext{
* Correspondence: pumclinyan@163.com

${ }^{\dagger}$ Equal contributors

'Department of Breast Disease, Peking Union Medical College Hospital, Peking Union Medical College, 1 Shuaifuyuan, Wangfujing, Beijing 100730, China

Full list of author information is available at the end of the article
}

cohort studies demonstrating a positive association [5-8] but other studies showing no association $[9,10]$.

An important stress disorder, called striking life events, has been classified as an acute anxiety disorder. This disorder is characterized by aversive anguishing experiences and physiological responses that develop after exposure to stressful life events, including change in marital status, such as separation, divorce, or widowhood; death of a spouse, child, or close relative; a friend's illness; personal health problems; and change in financial status. This disorder has short-term features, distinguishing it from chronic or delayed-onset stress disorder [11-13]. A prospective cohort study found that chronic stressful life events in women were associated with an increased incidence of breast cancer,

\section{Ciomed Central}


with the latter due to chronic stress-induced inhibition of estrogen synthesis, thus explaining the increased incidence of breast cancer in women exposed to long-term high degrees of stress [8]. By contrast, no case-control or cohort study performed to date has assessed the correlation between short-term exposure to stressful life events and the incidence of primary breast cancer.

Conflicting results regarding the association between stressful life events and breast cancer may be due to differences in subject population, number of subjects, study type, and sample type. These findings suggested the need for a meta-analysis examining the relationship between striking life events and primary breast cancer incidence in women.

\section{Methods}

\section{Purpose}

A systematic review and meta-analysis of primary cohort and case-control studies addressed whether women exposed to stressful life events are at increased risk of developing breast cancer. Hence, the objective was to evaluate the association between striking life events and primary breast cancer in women. The use of human materials was approved by the Peking Union Medical College Hospital Medical Ethics Committee (No.S-406).

\section{Study identification and selection}

Eligible studies were identified by systematic computerized searching of the PubMed, Science Direct, Embase, and BMJ databases for relevant reports published from January 1995 to April 2012. The database search strategy used combinations of controlled descriptors from Mesh, including breast cancer, breast tumor, cancer of breast, mammary carcinoma, life events, life change events, case-control studies, case-base studies, cohort study, and cohort analysis. The reference lists of the retrieved articles were also reviewed to identify additional articles missed by this search.

The following inclusion criteria were adopted for the studies: (a) type of study - prospective and historical cohort and case-control studies; (b) type of sample women aged 20 years or older at first occurrence of breast cancer in cohort studies and women with the appearance of first breast cancer in case-control studies; (c) mean follow-up time - a minimum of ten years in cohort studies, with no limit between exposure and diagnosis in case-control studies; (d) type of variables studies in which the stress variable was measured quantitatively, using a numerical scale, questionnaire, or checklist, with stress assessed by measuring the frequency of exposure and intensity of the event; (e) statistical type and analysis - studies that calculated relative risk (RR) for the first episode of breast cancer in relation to the stress variable, adjusting for confounding factors, including age, use of oral contraceptives, any type of hormone replacement, menopause, alcohol intake, smoking, socioeconomic status, and family history of breast cancer.

Studies were excluded if: (a) the articles which not had English version; (b) the articles addressed life style and daily stress; (c) stress was assessed in women with a psychiatric history; or (d) breast cancer recurrence or other diseases of the breast were measured. In addition, review articles and editorials were excluded.

\section{Strategy for article identification and selection and data collection}

The article titles and abstracts were initially evaluated by three reviewers to verify that each primary study addressed the underlying question of the systematic review. The abstracts were grouped into selected versus not selected. The selected articles were retrieved, read in full, and screened for those indexed in more than one source or in another language.

In the next phase, data from the selected studies were assigned to an instrument to verify whether they met the inclusion and exclusion criteria, with discrepancies resolved by discussion and consensus. Studies lacking a consensus for inclusion were analyzed by a fourth reviewer.

Data from the case-control and cohort studies were assigned to a structured form, which included the last name of the first author, the year of publication, country of origin, type of study, adjustment for confounding factors, and odds ratios (ORs) and 95\% confidence interval (CI). The data were reviewed by the four reviewers.

\section{Statistical analysis}

Statistical analysis was performed preferentially using Cochrane Review Manager Software (version 5.1). For categorical variables, weighted risk ratios and their 95\% CIs were calculated using RevMan 5.1 software [14]. Results were tested for heterogeneity at significance level of $P<0.05$ as described [15]. A fixed effects model was used if there was no evidence of heterogeneity among studies, whereas a random effects model was used if there was evidence of heterogeneity. The OR and 95\% CI for each trial were presented in a Forrest plot. Potential publication bias was assessed by funnel plots, with an asymmetric plot suggesting a possible publication bias. Funnel plot asymmetry was assessed by Egger's linear regression test using the standardized estimate of the size effect as the dependent variable and the inverse of the standard error as the independent variable. Results were considered statistically significant if $p<0.05$. 


\section{Results}

\section{Trials and patients}

The search strategy identified 307 titles and abstracts. Of these, 284 were excluded after reading the titles and abstracts. Our inclusion and exclusion criteria were applied to the remaining 23 articles describing case-control and cohort studies. A higher intensity of psychological events resulting from severe, major life, stressful, and overall life events were described and classified to calculate the ORs in these articles.

Of the 23 articles, seven, containing sufficient data, were included in our meta-analysis (Table 1). Most of these studies showed satisfactory methodological quality [16]. The cutoff point characterizing these studies as having a high methodological score was the median value of these studies (Table 1). Based on the Downs \& Black criteria, the maximum possible total scores were 20 and 18 points for cohort and case-control studies, respectively.

Of the seven studies included in our meta-analysis, four were case-control studies [17-20] and three were cohort studies [21-23]. The four case-control studies were from the United States, Poland, England, and Australia [17-20], with the U.S. study including maximum sized sample. The seven studies included 99,807 women, with age set at higher than 38 years, with one study setting age as more than 50 years.

The remaining 16 identified articles not included in our meta-analysis were examined. Risk factors related to psychiatric, psychological, and social disorders have been described [24]. In addition, the psychological factors and serum biochemical indices defining the association between life events and mye loid-derived suppressor cells were evaluated [25]. Studies have also evaluated the psychosocial approach [26-28], with life events contributing to delays in diagnosis and treatment [28]. Several studies referred to other types of stress (e.g. stresses associated with work, activities of daily life, or lifestyle, as well as post-traumatic stress) [27,29-33]. Indeed, one study found no association between life events and the incidence of breast cancer [34].

\section{Association between striking life events and the incidence of primary breast cancer}

ORs for primary breast cancer occurrence related to striking life events are shown in Table 1 . In the present study, striking life events was used as a marker of serious psychological events, including stress of life events and great life events. Analysis of ORs values and 95\% CIs regarding the association between stressful life events and the risk of breast cancer occurrence varied widely, due to high heterogeneity in the consistency test. We therefore abandoned the fixed effects model, with a random effects model used in the metaanalysis (Figure 1).

The consistency of the seven studies was poor and varied markedly ( $p<0.00001$, Figure 1$)$. Random effects model analysis showed that, in regard to striking life events, the overall OR was 1.51 (95\% CI 1.15 1.97), indicating that the risk of breast cancer was 1.5fold higher in populations with than without striking life events $(p=0.003)$. As shown in forest plots, rhombus shapes that represent the studied variable appeared on the right side of invalid line, suggesting the studied variable was a strong pathogenic factor. Interestingly, the rhombus shape suggested that the variable had not been characterized. The OR was far from the midline and differed markedly from other studies. The weight ratio depended on the model used for analysis, with a minimum weight box displayed in the forest plots. The maximal weight box did not represent those reported previously and included the highest number of samples (84,334 cases), although others had difference perspectives (10,808 cases). Although both were prospective cohort studies, subject age was limited from 50 to 79 years, with no specific age limitations.

\section{Association between severe striking life events and the incidence of primary breast cancer}

Of the 7 included studies, three described severe life events. In one study, life events were categorized into those with little or no threat, some threat, moderate threat, and severe threat, depending on subjective human feelings, with the OR of primary breast cancer higher in subjects with severe threat [17]. A second study evaluated severe life events based on scores, finding that $\mathrm{OR}$ of primary breast cancer increased from 5.09 to 5.33 as scores increased [20]. In contrast, when severe life events were based on multiple events, the OR for primary cancer decreased from 1.12 for a single event to 0.91 for more than three events [23]. To assess the reasons for these differences, we performed a metaanalysis regarding ORs of severe life events in the included studies because the phrase "severe life events" was close to the connotation of "striking life events" in the present study (Table 2). Because the analysis of Ors showed considerable heterogeneity in consistency tests, the fixed effects model was abandoned and the random effects model was used in our meta-analysis.

We found that the risk of breast cancer was strongly and significantly associated with more severe striking life events (OR 2.07, 95\% CI 1.06 - 4.03, $P=0.03$ ), suggesting that individuals with severe striking life events would be at two-fold greater risk of developing breast cancer than individuals without these severe striking life events (Figure 2). In addition, we found 
Table 1 Characteristics and downs \& black scores of studies included in the meta-analysis

\begin{tabular}{|c|c|c|c|c|c|c|c|c|c|c|c|c|}
\hline Authors/Year & Country & Design & $\begin{array}{l}\text { Assessment } \\
\text { instruments }\end{array}$ & $\begin{array}{l}\text { Sample } \\
\text { size }\end{array}$ & Age & Type of stress & Specific events & $\begin{array}{c}\text { Evaluation } \\
\text { moment }\end{array}$ & $\begin{array}{l}\text { Disease } \\
\text { stage }\end{array}$ & $\begin{array}{l}\text { Type of } \\
\text { treatment }\end{array}$ & $\begin{array}{l}\text { Result RR } \\
(95 \% \mathrm{Cl})\end{array}$ & Score \\
\hline Chen 1995 [17] & England & $\begin{array}{l}\text { Case- } \\
\text { control }\end{array}$ & $\begin{array}{l}4 \text { point scale } \\
\text { (great, } \\
\text { moderate, } \\
\text { some, and little } \\
\text { or no) }\end{array}$ & $41 / 78$ & $20-70$ & Great life events & None & $\begin{array}{c}\text { No } \\
\text { description }\end{array}$ & All stages & $\begin{array}{c}\text { No } \\
\text { description }\end{array}$ & $7.08(2.31-21.65)$ & 18 \\
\hline Roberts 1996 [18] & America & $\begin{array}{l}\text { Case- } \\
\text { control }\end{array}$ & $\begin{array}{l}\text { Holmes-Rahe } \\
\text { life-event } \\
\text { weights }\end{array}$ & $258 / 614$ & $50-79$ & $\begin{array}{l}\text { Stressful life } \\
\text { events }\end{array}$ & $\begin{array}{c}\text { Allow for both } \\
\text { shorter time of } \\
\text { administration and } \\
\text { appropriateness } \\
\text { (primarily older } \\
\text { women) }\end{array}$ & $\begin{array}{l}\text { During the } \\
\text { previous } \\
5 \text { years }\end{array}$ & All stages & $\begin{array}{l}\text { Hormone } \\
\text { replacement } \\
\text { therapy }\end{array}$ & $0.9(0.78-1.05)$ & 18 \\
\hline \multirow[t]{2}{*}{ Protheroe 1999 [19] } & \multirow[t]{2}{*}{ Australia } & \multirow[t]{2}{*}{$\begin{array}{l}\text { Case- } \\
\text { control }\end{array}$} & \multirow{2}{*}{$\begin{array}{c}\text { Four point } \\
\text { scale, and six } \\
\text { point scale for } \\
\text { severity } \\
\text { difficulties } \\
\text { lasting } 4 \text { weeks }\end{array}$} & \multirow[t]{2}{*}{$106 / 226$} & \multirow[t]{2}{*}{$40-79$} & \multirow[t]{2}{*}{$\begin{array}{l}\text { Stressful life } \\
\text { events }\end{array}$} & \multirow{2}{*}{$\begin{array}{l}\text { Excluded events that } \\
\text { were related to past } \\
\text { and present breast } \\
\text { problems, or a first } \\
\text { degree relative's } \\
\text { breast cancer }\end{array}$} & \multirow[t]{2}{*}{$\begin{array}{l}\text { During the } \\
\text { previous } \\
5 \text { years }\end{array}$} & All stages & $\begin{array}{l}\text { Hormone } \\
\text { replacement } \\
\text { therapy }\end{array}$ & \multirow[t]{2}{*}{$0.91(0.47-1.81)$} & \multirow[t]{2}{*}{17} \\
\hline & & & & & & & & & & $\begin{array}{c}\text { Oral } \\
\text { contraceptives }\end{array}$ & & \\
\hline Kruk 2012 [20] & Poland & $\begin{array}{l}\text { Case- } \\
\text { control }\end{array}$ & $\begin{array}{l}\text { Holmes-Rahe } \\
\text { life-event } \\
\text { weights }\end{array}$ & $858 / 1085$ & $28-79$ & Life events & $\begin{array}{l}\text { The association } \\
\text { between job stress } \\
\text { and breast cancer } \\
\text { was determined in } \\
\text { separate analysis }\end{array}$ & $\begin{array}{l}\text { During the } \\
\text { previous } \\
3 \text { years }\end{array}$ & All stages & $\begin{array}{l}\text { Hormone } \\
\text { replacement } \\
\text { therapy }\end{array}$ & $5.09(3.41-8.50)$ & 18 \\
\hline Helgesson 2003 [21] & Sweden & Prospective & $\begin{array}{l}1-6 \text { on the } \\
\text { stress scale }\end{array}$ & 1462 & $38-60$ & Stressful events & None & $\begin{array}{l}\text { During the } \\
\text { previous } \\
5 \text { years }\end{array}$ & All stages & $\begin{array}{c}\text { No } \\
\text { description }\end{array}$ & $2.1(1.2-3.7)$ & 20 \\
\hline Lillberg 2003 [22] & Finland & Prospective & $\begin{array}{l}\text { Holmes-Rahe } \\
\text { life-event } \\
\text { weights }\end{array}$ & 10808 & $>24$ & $\begin{array}{l}\text { Stressful life } \\
\text { events }\end{array}$ & None & $\begin{array}{l}\text { During the } \\
\text { previous } \\
5 \text { years }\end{array}$ & All stages & $\begin{array}{c}\text { Oral } \\
\text { contraceptives }\end{array}$ & $1.07(1.00-1.15)$ & 20 \\
\hline Michael 2009 [23] & America & Prospective & $\begin{array}{l}\text { Number of life } \\
\text { events and } \\
\text { amount of } \\
\text { upset }\end{array}$ & 84334 & $50-79$ & Life events & None & $\begin{array}{l}\text { During the } \\
\text { previous } \\
1 \text { years }\end{array}$ & All stages & $\begin{array}{c}\text { No } \\
\text { description }\end{array}$ & $1.12(1.01-1.25)$ & 19 \\
\hline
\end{tabular}

$R R$ relative risk, $\mathrm{Cl}$ confidence interval. 


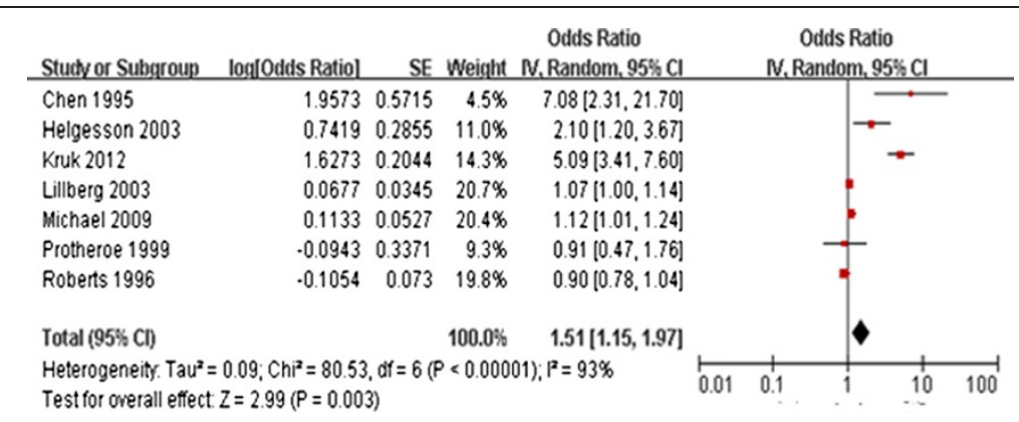

Figure 1 Meta-analysis of the relative risk, or odds ratio, for the association between striking life events and primary breast cancer incidence. Solid squares represent risk estimates for the individual studies, with the size of the squares proportional to the sample size and the number of events. Horizontal lines denote $95 \%$ confidence intervals $(\mathrm{Cls})$. The diamond shows the confidence interval for the pooled relative risks. Positive values indicate an increased relative risk for primary breast cancer development. Test for overall effect: $Z=2.99, P<0.01$; chi-square test for heterogeneity $=80.53$, degrees of freedom $=6, P<0.001 ; I^{2}=93 \%$.

that the risk of breast cancer incidence was positively associated with both striking (OR 1.51) and severe striking life events (OR 2.07) in the population.

\section{Discussion}

Primary breast cancer is the most common malignant disease in women. Although many studies have assessed the relationship between the incidence of breast cancer and life events, both epidemiologically and etiologically, the results have been inconsistent [35-37]. Several of these studies reported that life events were significantly associated with breast cancer risk $[37,38]$. Evidence has emerged showing that these life events may affect the hypothalamic-pituitaryadrenal axis, resulting in endocrine system disorders, increased cortisol concentrations, and reductions in antineoplastic activity $[7,8,39]$. However, some studies found that stressful life events were not associated with the development of primary breast cancer [40,41]. The first meta-analysis, which included 29 studies, showed a lack of a causal relationship between negative life events and breast cancer incidence [39]. The second meta-analysis, which included 27 studies, assessed several categories of stressful life events, including death of a husband, death of a friend, health problems, financial problems, and change in marital status [41]. Although there was no association between stressful events and breast cancer, there was a slight association between death of a husband and risk of breast cancer. Moreover, it was unclear whether a high degree of depression and anxiety induced by life events, resulting in immune suppression, would promote breast cancer risk, especially when organ transplant recipients who receive immune suppression therapy did not develop multiple malignancies [42-45].

A meta-analysis is a quantitative overview of multiple studies, with evaluation criteria assessing the quality and controlling for selection bias being extremely important. We therefore utilized the Downs \& Black method of assessing literature quality to minimize the uneven quality of data collection, criteria used in other meta-analyses and systematic reviews [46-48]. Considering the methodological quality of the reviewed articles, the seven studies included in our meta-analysis were methodologically homogeneous. However, the limitation of populations in some cohort studies to older patients may introduce a selection bias to observed psychological changes after life events. Nevertheless, our meta-analysis selected articles published over 17 years to show that, despite differences in research methods, striking life events remained associated with primary breast cancer incidence.

Psychologically, being in a depressed state and life events are somewhat connected as well as being

Table 2 Characteristics and downs \& black scores of studies assessing serious striking life events

\begin{tabular}{|c|c|c|c|c|}
\hline Authors/Year & Country & Design & Valable & OR $(95 \% \mathrm{Cl})$ \\
\hline Chen 1995 [17] & England & Case-control & Severe life events & $11.64(3.10-43.66)$ \\
\hline Protheroe 1999 [19] & Australia & Case-control & Severe life events & $0.91(0.47-1.81)$ \\
\hline Kruk 2012 [20] & Poland & Case-control & Major life events & $5.33(4.01-8.21)$ \\
\hline Helgesson 2003 [21] & Sweden & Prospective & Stressful events & $2.1(1.2-3.7)$ \\
\hline Lillberg 2003 [22] & Finland & Prospective & Major life events & $1.35(1.09-1.67)$ \\
\hline Michael2009 [23] & America & Prospective & $\geq 4$ life events & $0.91(0.77-1.08)$ \\
\hline
\end{tabular}

$R R$ relative risk, $C l$ confidence interval. 


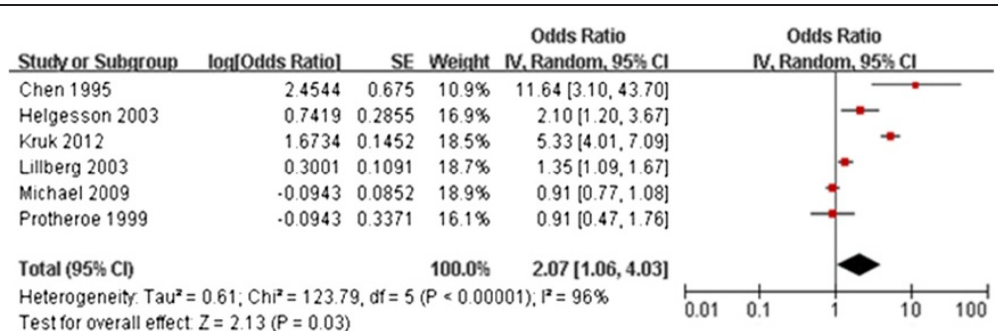

Figure 2 Meta-analysis of the relative risk, or odds ratio, for the association between severe striking life events and primary breast cancer incidence. Solid squares represent risk estimates for the individual studies. The size of the squares is proportional to the sample size and the number of events. The horizontal lines denote $95 \%$ confidence intervals $(\mathrm{Cls})$. The diamond shows the confidence interval for the pooled relative risks. Positive values indicate an increased relative risk for primary breast cancer incidence. Test for overall effect: $Z=2.23, P<0.01$; chi-square test for heterogeneity $=123.79$, degrees of freedom $=5, P<0.001 ; I^{2}=96 \%$.

different. Being depressed is a continuing psychological status, whereas life events are associated with shortterm inner feelings and thoughts. An increasing number of retrospective and prospective studies, including a wide range of sample sizes, have shown the importance of the relationship between life events and the occurrence of breast cancer. Among various types of life events, we found that striking life events contributed more to tumor development. Interestingly, severe life events, important life changes, major life events, severe threat events, and great threat events have been used to describe the similar psychological characteristics of striking life events in this study [17-21].

The seven selected studies differed somewhat in their definition of striking life events. One study divided individual feelings into four levels, severe, moderate, some, and little or no, with severe feelings defined as striking life events [17]. A second study defined striking life events as death of a spouse, family member, or friend; sickness of a family member; sickness of the individual (except for cancer); divorce; economic events; self or spouse retirement or unemployment; and moving one's residence, suggesting that these be considered a standard set of evaluations of striking life events [18]. Since the inclusion of divorce may be open to different interpretations and may result in a lack of significance of the results, we removed this study from our analysis. A third study defined striking life events by their respective scores or as the numbers of events [20]. Although many previous studies have utilized number rather than degree, validation requires larger patient populations.

Our meta-analysis found that women with striking life events were at 1.5-fold higher risk of developing breast cancer than women without these striking life events (combined OR 1.51, 95\% CI 1.15 - 1.97). A forest plot showed a diamond shape, with striking life events on the right side of the invalid line, suggesting that striking life events were strongly associated with the incidence of primary breast cancer. However, although our results indicated that striking life events were positively associated with breast cancer occurrence, the OR was not high and the lower limit of the 95\% CI was only 1.15 .

More importantly, our meta-analysis found that women with a severe degree of striking life events had an OR of 2.07 (95\% CI 1.06 - 4.03) of developing breast cancer, suggesting that more severe striking life events contribute to a higher risk of primary breast cancer in women. Our findings suggest that psychological treatment of striking life events may reduce breast cancer occurrence. Discrepancies over the definition of striking life events would change the association between these events and the risk of developing breast cancer.

\section{Conclusions}

Although studies have yielded contradictory results on the association between stress and breast cancer development, our results confirm that high-intensity stress has a borderline association with the development of breast cancer. However, relative to the findings in most of studies that stress can increase the risk of breast cancer, whether those women who had the most aggressive form of breast cancer also had the highest stress levels was unclear, and there is no real way to tell how much stress the women were under before their diagnosis of breast cancer. Obviously, based on that it's not clear what's driving the association between stress and breast cancer development, future studies are necessary to elucidate this relationship.

Competing interests

The authors declare that they have no competing interests.

\section{Authors' contributions}

$Y L$ and $C W$ contributed equally to this work. Both designed the study, collected and analyzed data, and wrote the manuscript. $Y Z, X H$, and LP participated in the collecting and analyzing data. GS and KW performed statistical analyses. QS conceived the study, participated in its design, and helped to draft the manuscript. All authors read and approved the final manuscript. 


\section{Author details}

'Department of Breast Disease, Peking Union Medical College Hospital, Peking Union Medical College, 1 Shuaifuyuan, Wangfujing, Beijing 100730, China. ${ }^{2}$ Department of Epidemiology, Insititue of Basic Medical Sciences, Peking Union Medical College, Beijing 100730, China.

Received: 1 July 2013 Accepted: 10 August 2013

Published: 13 August 2013

\section{References}

1. Jemal A, Bray F, Center MM, Ferlay J, Ward E, Forman D: Global cancer statistics. CA Cancer J Clin 2011, 61:69-90.

2. Tyrer J, Duffy SW, Cuzick J: A breast cancer prediction model incorporating familial and personal risk factors. Stat Med 2004, 23(7):1111-1130.

3. Curtis C, Shah SP, Chin SF, Turashvili G, Rueda OM, Dunning MJ, Speed D, Lynch AG, Samarajiwa S, Yuan Y, Gräf S, Ha G, Haffari G, Bashashati A, Russell R, McKinney S, METABRIC Group, Langerød A, Green A, Provenzano E, Wishart G, Pinder S, Watson P, Markowetz F, Murphy L, Ellis I, Purushotham A, Børresen-Dale AL, Brenton JD, Tavaré S, Caldas C, Aparicio S: The genomic and transcriptomic architecture of 2,000 breast tumours reveals novel subgroups. Nature 2012, 486(7403):346-352.

4. Hulka BS, Moorman PG: Breast cancer: hormones and other risk factors. Maturitas 2001, 38(1):103-113.

5. van den Brandt PA, Spiegelman D, Yaun SS, Adami HO, Beeson L, Folsom AR, Fraser G, Goldbohm RA, Graham S, Kushi L, Marshall JR, Miller AB, Rohan T, Smith-Warner SA, Speizer FE, Willett WC, Wolk A, Hunter DJ: Pooled analysis of prospective cohort studies on height, weight, and breast cancer risk. Am J Epidemiol 2000, 152(6):514-527.

6. Santen RJ, Boyd NF, Chlebowski RT, Cummings S, Cuzick J, Dowsett M, Easton D, Forbes JF, Key T, Hankinson SE, Howell A, Ingle J, Breast Cancer Prevention Collaborative Group: Critical assessment of new risk factors for breast cancer: considerations for development of an improved risk prediction model. Endocr Relat Cancer 2007, 14(2):169-187.

7. Glaser R, Kiecolt-Glaser JK: Stress-induced immune dysfunction: implications for health. Nat Rev Immunol 2005, 5(3):243-251.

8. Schernhammer ES, Hankinson SE, Rosner B, Kroenke CH, Willett WC, Colditz GA, Kawachi I: Job stress and breast cancer risk: the nurses' health study. Am J Epidemiol 2004, 160(11):1079-1086.

9. Surtees PG, Wainwright NW, Luben RN, Khaw KT, Bingham SA: No evidence that social stress is associated with breast cancer incidence. Breast Cancer Res Treat 2010, 120(1):169-174.

10. Edwards JR, Cooper CL, Pearl SG, de Paredes ES, O'Leary T, Wilhelm MC: The relationship between psychosocial factors and breast cancer: some unexpected results. Behav Med 1990, 16(1):5-14

11. Wang HH, Chung UL: Healthy lifestyle changes during the period before and after cancer diagnosis among breast cancer survivors. Asian Pac $J$ Cancer Prev 2012, 13(9):4769-4772.

12. Kaplan HI, Sadock BJ, Grebb JA: Kaplan and Sadock's synopsis of psychiatry: Behavioral sciences, clinical psychiatry. 7th edition. Baltimore: Williams \& Williams: 1994:606-609.

13. Tas F, Karalar U, Aliustaoglu M, Keskin S, Can G, Cinar FE: The major stressful life events and cancer: stress history and cancer. Med Oncol 2012, 29(2):1371-1377

14. Viani GA, Afonso SL, Stefano EJ, De Fendi LI, Soares FV: Adjuvant trastuzumab in the treatment of her-2-positive early breast cancer: a meta-analysis of published randomized trials. BMC Cancer 2007, 7:153-164.

15. DerSimonian R, Laird N: Meta-analysis in clinical trials. Control Clin Trials 1986, 7:177-188.

16. Downs SH, Black N: The feasibility of creating a checklist for the assessment of the methodological quality both of randomized and non-randomized studies of health care interventions. J Epidemiol Community Health 1998, 52:377-384.

17. Chen CC, David AS, Nunnerley H, Michell M, Dawson JL, Berry H, Dobbs J, Fahy T: Adverse life events and breast cancer: case-control study. BMJ 1995, 311(7019):1527-1530.

18. Roberts FD, Newcomb PA, Trentham-Dietz A, Storer BE: Self-reported stress and risk of breast cancer. Cancer 1996, 77(6):1089-1093.
19. Protheroe D, Turvey K, Horgan K, Benson E, Bowers D, House A: Stressful life events and difficulties and onset of breast cancer: case-control study. BMJ 1999, 319(7216):1027-1030.

20. Kruk J: Self-reported psychological stress and the risk of breast cancer: a case-control study. Stress 2012, 15(2):162-171.

21. Helgesson O, Cabrera C, Lapidus L, Bengtsson C, Lissner L: Self-reported stress levels predict subsequent breast cancer in a cohort of Swedish women. Eur J Cancer Prev 2003, 12(5):377-381.

22. Lillberg K, Verkasalo PK, Kaprio J, Teppo L, Helenius H, Koskenvuo M: Stressful life events and risk of breast cancer in 10,808 women: a cohort study. Am J Epidemiol 2003, 157(5):415-423.

23. Michael YL, Carlson NE, Chlebowski RT, Aickin M, Weihs KL, Ockene JK, Bowen DJ, Ritenbaugh C: Influence of stressors on breast cancer incidence in the women's health initiative. Health Psychol 2009, 28(2):137-146.

24. Burgess CC, Ramirez AJ, Smith P, Richards MA: Do adverse life events and mood disorders influence delayed presentation of breast cancer? J Psychosom Res 2000, 48(2):171-175.

25. Butler LD, Koopman C, Classen C, Spiegel D: Traumatic stress, life events, and emotional support in women with metastatic breast cancer: cancerrelated traumatic stress symptoms associated with past and current stressors. Health Psychol 1999, 18(6):555-560.

26. Cooper CL, Faragher EB: Psychosocial stress and breast cancer: the inter-relationship between stress events, coping strategies and personality. Psychol Med 1993, 23(3):653-662.

27. Dorval M, Drolet M, LeBlanc M, Maunsell E, Dugas MJ, Simard J: Using the impact of event scale to evaluate distress in the context of genetic testing for breast cancer susceptibility. Psychol Rep 2006, 98(3):873-881.

28. Forsen A: Psychosocial stress as a risk for breast cancer. Psychother Psychosom 1991, 55(2-4):176-185.

29. Geyer S: Life events prior to manifestation of breast cancer: a limited prospective study covering eight years before diagnosis. J Psychosom Res 1991, 35(2-3):355-363.

30. Geyer S: Life events, chronic difficulties and vulnerability factors preceding breast cancer. Soc Sci Med 1993, 37(12):1545-1555.

31. Geyer S, Noeres D, Mollova M, Sassmann H, Prochnow A, Neises M: Does the occurrence of adverse life events in patients with breast cancer lead to a change in illness behaviour? Support Care Cancer 2008, 16(12):1407-1414

32. Kricker A, Price M, Butow P, Goumas C, Armes JE, Armstrong BK: Effects of life event stress and social support on the odds of $\mathrm{a}>$ or $=2 \mathrm{~cm}$ breast cancer. Cancer Causes Control 2009, 20(4):437-447.

33. Kruk J, Aboul-Enein HY: Psychological stress and the risk of breast cancer: a case-control study. Cancer Detect Prev 2004, 28(6):399-408.

34. Mundy-Bosse BL, Thornton LM, Yang HC, Andersen BL, Carson WE: Psychological stress is associated with altered levels of myeloid-derived suppressor cells in breast cancer patients. Cell Immunol 2011, 270(1):80-87.

35. Palesh O, Butler LD, Koopman C, Giese-Davis J, Carlson R, Spiegel D: Stress history and breast cancer recurrence. J Psychosom Res 2007, 63(3):233-239.

36. Peled R, Carmil D, Siboni-Samocha O, Shoham-Vardi I: Breast cancer, psychological distress and life events among young women. BMC Cancer 2008, 8:245.

37. Santos MC, Horta BL, Amaral JJ, Fernandes PF, Galvão CM, Fernandes AF: Association between stress and breast cancer in women: a meta-analysis. Cad Saude Publica 2009, 25(Suppl 3):S453-S463.

38. Black AR, Woods-Giscombé C: Applying the stress and 'strength' hypothesis to black women's breast cancer screening delays. Stress Health 2012, 28(5):389-396.

39. Lillberg K, Verkasalo PK, Kaprio J, Teppo L, Helenius H, Koskenvuo M: Stress of daily activities and risk of breast cancer: a prospective cohort study in Finland. Int J Cancer 2001, 91(6):888-893.

40. Kroenke $\mathrm{CH}$, Hankinson SE, Schernhammer ES, Colditz GA, Kawachi Holmes MD: Caregiving stress, endogenous sex steroid hormone levels, and breast cancer incidence. Am J Epidemiol 2004, 159(11):1019-1027.

41. Petticrew M, Fraser J, Regan MF: Adverse life events and risk of breast cancer: a meta-analysis. Br J Health Psychol 1999, 4:1-17.

42. Duijts SFA, Zeegers MP, Borne BV: The association between stressful life events and breast cancer risk: a meta-analysis. Int J Cancer 2003, 107:1023-1029. 
43. Adami J, Gäbel H, Lindelöf B, Ekström K, Rydh B, Glimelius B, Ekbom A, Adami HO, Granath F: Cancer risk following organ transplantation: a nationwide cohort study in Sweden. Br J Cancer 2003, 89(7):1221-1227.

44. Vajdic CM, van Leeuwen MT: Cancer incidence and risk factors after solid organ transplantation. Int J Cancer 2009, 125(8):1747-1754.

45. Vajdic CM, McDonald SP, McCredie MR, van Leeuwen MT, Stewart JH, Law M, Chapman JR, Webster AC, Kaldor JM, Grulich AE: Cancer incidence before and after kidney transplantation. JAMA 2006, 296(23):2823-2931.

46. Buscemi N, Vandermeer B, Hooton N, Pandya R, Tjosvold L, Hartling L, Vohra S, Klassen TP, Baker G: Efficacy and safety of exogenous melatonin for secondary sleep disorders and sleep disorders accompanying sleep restriction: meta-analysis. BMJ 2006, 332:385-393.

47. Nomura K, Nakao M, Morimoto T: Effect of smoking on hearing loss: quality assessment and metaanalysis. Prev Med 2005, 40:138-144.

48. Brouwers MC, Johnston ME, Charette ML, Hanna SE, Jadad AR, Browman GP: Evaluating the role of quality assessment of primary studies in systematic reviews of cancer practice guidelines. BMC Med Res Methodol 2005, 5:8.

doi:10.1186/1756-9966-32-53

Cite this article as: Lin et al:: Striking life events associated with primary breast cancer susceptibility in women: a meta-analysis study. Journal of Experimental \& Clinical Cancer Research 2013 32:53.

\section{Submit your next manuscript to BioMed Central and take full advantage of:}

- Convenient online submission

- Thorough peer review

- No space constraints or color figure charges

- Immediate publication on acceptance

- Inclusion in PubMed, CAS, Scopus and Google Scholar

- Research which is freely available for redistribution 